\title{
Factors associated with grain feeding in dairy farms located in the central-western region of Paraná State, Brazil
}

\section{Fatores associados ao uso de grãos em fazendas leiteiras localizadas na região centro-oeste do Estado do Paraná, Brasil}

\author{
Pedro Gustavo Loesia Lima; Julio Cesar Damasceno², João Augusto Rossi \\ Borges $^{3}$, Ferenc Istvan Bánkuti², Raiane Real Martinelli*
}

\section{Highlights}

Factors associated with grain feeding determine the typology of dairy farms;

Grain feeding is associated with diet quality, technology, and breeding composition;

Farm productivity is associated with the supply of grains to the cows.

\section{Abstract}

This study aimed to investigate factors associated with grain feeding and determine the typology of dairy farms that use high-grain diets. Twenty-two farm operators were interviewed in three municipalities located in the central-western region of Paraná state, Brazil. Information on reproductive and nutritional management practices, sociodemographic characteristics, and farm performance was collected. Data were analyzed using exploratory factor analysis, hierarchical cluster analysis, and multiple linear regression. Three factors (F1, F2, and F3) were extracted, which together explained $82.61 \%$ of the total variance. F1 comprised diet quality, technology, and breeding composition. F2 comprised labor and size. F3 comprised feed quality and schooling. Farms were classified into four groups and compared in terms of factor scores and performance parameters. Group 1 had the highest mean score on F1 (0.715), group 4 on F2 (1.642), and group 2 on F3 (1.116). Groups 4 and 1 had the highest milk productivity (2043.50 and $399.52 \mathrm{~L} \mathrm{day}^{-1}$, respectively) and labor efficiency (418.16 and $148.63 \mathrm{~L}_{\text {worker }}^{-1}$ day $^{-1}$, respectively). Group 4 also had the highest mean number of cows per worker (25.52 cows worker-1). Regression analysis revealed that diet quality, technology, and breeding composition (F1) explained the variance in cow productivity. Labor

1 Drs. in Animal Science, Department of Animal Science, Universidade Estadual de Maringá, UEM, Maringá, PR, Brazil. E-mail: pedroloesia@gmail.com; raiane.rm@hotmail.com

2 Profs. Drs., Department of Animal Science, Universidade Estadual de Maringá, UEM, Maringá, PR, Brazil. E-mail: jcdamasceno@uem.br; ferencistvan@gmail.com

${ }^{3}$ Prof. Dr., Faculty of Administration, Accounting and Economies, Universidade Federal de Grande Dourados, UFGD, Dourados, MS, Brazil. E-mail: joaoborges@ufgd.edu.br

* Author for correspondence

Received: Mar. 08, 2021 - Approved: July 22, 2021 
and size, (F2) explained the variance in number of cows per worker. Daily productivity and labor efficiency were explained by both F1 and F2. Feed quality and farm operator's level of schooling did not explain the variation in any of the variables. We found that roughage quality, breeding technology, and herd breed composition are the major factors associated with grain feeding. Farmers who feed cows high-quality roughage throughout the year and invest in genetic improvement and selective breeding strategies are more likely to adopt high-grain feeding and have high milk productivity.

Key words: Animal feed. Concentrate. Farm typology. Multivariate approach.

\section{Resumo}

Este estudo teve como objetivo investigar os fatores associados ao uso de grãos e determinar a tipologia de fazendas leiteiras que utilizam dietas ricas em grãos. Foram entrevistados 22 produtores rurais em três municípios localizados na região centro-oeste do estado do Paraná, Brasil. As informações foram coletadas sobre práticas de manejo reprodutivo e nutricional, características sociodemográficas e desempenho da fazenda. Os dados foram analisados por meio de análise fatorial exploratória, análise de agrupamento hierárquico e regressão linear múltipla. Foram extraídos três fatores (F1, F2 e F3), que juntos explicaram $82,61 \%$ da variância total. F1 compreendeu uso de grãos, qualidade da dieta, estratégia de melhoramento genético e composição racial do rebanho. F2 compreendeu as características da força de trabalho, tamanho do rebanho e tamanho da fazenda. F3 compreendeu o nível de escolaridade e a qualidade da alimentação. As fazendas foram classificadas em quatro grupos e comparadas em termos de escores dos fatores e variáveis de desempenho. O grupo 1 teve a maior escore médio em F1 $(0,715)$, o grupo 4 em F2 $(1,642)$ e o grupo 2 em F3 $(1,116)$. Os grupos 4 e 1 tiveram a maior produtividade de leite (2043,50 e 399,52 L dia-1 ${ }^{-1}$ respectivamente) e eficiência de trabalho $\left(418,16\right.$ e 148,63 $\mathrm{L} \mathrm{trabalhador}^{-1}$ dia $^{-1}$, respectivamente). O Grupo 4 também teve o maior número médio de vacas por trabalhador $(25,52$ vacas trabalhador ${ }^{-1}$ ). A análise de regressão revelou que a qualidade da dieta, estratégia de criação e composição do rebanho (F1) explicaram a variação na produtividade das vacas. As características da força de trabalho, tamanho do rebanho e tamanho da fazenda (F2) explicaram a variação no número de vacas por trabalhador. A produtividade diária e a eficiência do trabalho foram explicadas por F1 e F2. A qualidade da alimentação e o nível de escolaridade do produtor rural não explicaram a variação em nenhuma das variáveis. Descobrimos que a qualidade do volumoso, a tecnologia de melhoramento genético dos animais e a composição do rebanho são os principais fatores associados à alimentação a base de grãos. Os produtores que alimentam as vacas com volumoso de alta qualidade ao longo do ano e investem em melhoramento genético e estratégias reprodutivas têm maior probabilidade de adotar alto teor de grãos na dieta das vacas e ter alta produtividade.

Palavras-chave: Alimentação animal. Concentrado. Tipologia. Abordagem multivariada. 


\section{Introduction}

The state of Paraná ranks among the largest milk-producing states in Brazil. Over 3.4 billion liters of milk were produced in 2017 , accounting for $11.3 \%$ of the total milk production in the country (Instituto Brasileiro de Geografia e Estatística [IBGE], 2017; Secretaria de Estado da Agricultura e do Abastecimento [SEAB], 2019b,a). Paraná is also a major grain producer and exporter. Soybean and maize are the most important crops grown in the state. In the $2017 / 2018$ harvest, Paraná produced 19.1 million tonnes of soybean and 11.9 million tonnes of maize, which accounted for 16.05 and $14.73 \%$ of Brazilian soybean and maize production, respectively. These grains are the main sources of energy and protein in concentrate feed for dairy animals (Goes, Silva, \& Souza, 2013).

Dairy cows have the biological ability to convert low-value grains into high-value animal products. Supplementation of cattle diets with grain-based concentrate is a value-adding strategy to transform grains into milk (Bargo, Muller, Kolver, \& Delahoy, 2003; Gonzalez-Rivas et al., 2018). The use of high levels of grains in dairy cattle diets has been linked to several benefits, including greater digestibility and energy use, increased production efficiency, increased milk production, increased herd productivity, and reduced greenhouse gas emission ( GonzalezRivas et al., 2018; Hurtaud, Chesneau, Coulmier, \& Peyraud, 2013; Hynes, Stergiadis, Gordon, \& Yan, 2016; Jiao, Dale, Carson, Gordon, \& Ferris 2014; Mendes et al., 2013). Increasing the scale of milk production may translate into higher profits, possibly leading to the expansion of rural jobs and retention of young generations in the dairy business. Such benefits are likely to provide competitiveness gains (Beber, Carpio, Almadani, \& Theuvsend, 2019). Productivity growth is necessary to make use of the idle capacity of the Brazilian dairy industry (Baptista, Sugamosto, \& Wavruk, 2011).

Although the relationship between milk production, total dry matter intake, and grain intake has been extensively investigated (Hills, Wales, Dunshea, Garcia, \& Roche 2015; Hurtaud et al., 2013; Hynes et al., 2016; Jiao et al., 2014), few studies analyzed associations between these parameters and characteristics of dairy production systems, such as reproductive management strategies, labor force, and sociodemographic characteristics of decision-makers (Duncan et al., 2013; Janssen \& Swinnen, 2017). Such investigation is necessary because several systemic factors interfere with the frequency and amount of grains fed to dairy cattle, from the quality of forage management, breeding management, and herd breed composition to grain storage capacity (Biradar \& Kumar, 2013; Denis-Robichaud, Cerri, Jones-Bitton, \& LeBlanc, 2016; DeVries, Holtshausen, Oba, \& Beauchemin, 2011; García, Dorward, \& Rehman, 2012; Hills et al., 2015; Li et al., 2016; Macdonald et al., 2017; Yabe, Bánkuti, Damasceno, \& Brito, 2015). In this study, we investigated the factors associated with grain feeding and the typology of dairy farms that use high-grain feeding in three major grain-producing municipalities in centralwestern Paraná, Brazil. Milk production in central-western Paraná has great economic and social importance. The dairy activity has created many jobs in rural areas, reducing unemployment and social exclusion (Bánkuti \& Caldas, 2018; IBGE, 2017). 


\section{Material and Methods}

The semi-structured questionnaire was approved by the Human Research Ethics Committee (written consent, process no. 2.396.173) of the State University of Maringá, Brazil.

\section{Study region and data collection}

A total of 22 dairy farms located in

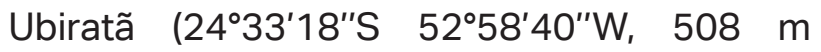
elevation), Campina da Lagoa (24⒊'30"S $52^{\circ} 47^{\prime} 56^{\prime \prime} \mathrm{W}, 561 \mathrm{~m}$ elevation), and Mamborê (2419'10"S, 52³1'48"W, 750 m elevation), Paraná, Brazil, participated in the study. The following criteria were used to select dairy farms: (i) farms should adequately represent the productive characteristics and feeding practices of other farms located in the region (Yabe et al., 2015; Zoma-Traoré et al., 2020) and (ii) the sample size should meet the requirements for multivariate statistical analyses. Thus, at least one observation should be obtained for each input variable (Barrett \& Kline, 1981; Hair, Black, Babin, \& Anderson 2009), and the number of observations should exceed the number of parameters estimated by multiple linear regression (Hair et al., 2009; Koerich, Damasceno, Bánkuti, Parré, \& Santo, 2019). To meet the selection criteria, we consulted experts who work in the dairy industry in Paraná, including researchers in milk production in the state and technicians from the Institute of Technical Assistance and Rural Extension (EMATER), who provide services to farmers in the analyzed region and the entire state (Bánkuti, Caldas, Bánkuti, \& Granco, 2017; Yabe et al., 2015; Zoma-Traoré et al., 2020).
A semi-structured questionnaire was applied to farm operators. Information was gathered on 20 variables, including grain supply, grain type, roughage type, use of concentrate, breeding practices, herd breed composition, type of labor, sociodemographic characteristics, sources of income, and marketing strategies. Answers were presented in ascending order of score (Bánkuti et al., 2020; García et al., 2012; Prospero-Bernal, Martínez-García, Olea-Pérez, López-González, \& Arriaga-Jordán, 2017). The questionnaire also included questions on six variables related to farm performance: cow productivity $\left(\mathrm{L} \mathrm{cow}^{-1}\right.$ day $\left.^{-1}\right)$, total daily production $\left(\mathrm{L} \mathrm{day}^{-1}\right)$, productivity per area $\left(\mathrm{L} \mathrm{ha}^{-1}\right.$ day $\left.^{-1}\right)$, stocking density (cows ha ${ }^{-1}$ ), labor efficiency (L worker ${ }^{-1}$ day $^{-1}$ ), and number of cows per worker (cows worker ${ }^{-1}$ ).

\section{Data analysis}

\section{Sample characterization}

Descriptive statistics (mean, maximum, minimum, and standard deviation) were used to analyze the characteristics of farm operators (age and farming experience) and farms (number of workers, total farm size, dairy production area, number of dairy cows, and daily productivity).

\section{Exploratory factor analysis}

Exploratory factor analysis was conducted to identify factors associated with the use of grains in cow diets. This dimension reduction technique condenses a large 
number of variables into common factors or components. Variables that define a factor show a strong correlation with each other but a low correlation with variables that compose other factors (Fávero, Belfiore, Silva, \& Chan, 2009; Hair et al., 2009).

First, we standardized the management variables. Means equal to zero (0.0) and standard deviations equal to one (1.0) were obtained. This procedure avoided problems related to differences in units of measure and stabilized variances for the determination of factor loadings (Field, 2009; Simões, Reis, \& Avelar, 2017). After variable standardization, the model was applied as follows (equation 1):

$$
X_{p}=a_{p 1} \times F_{1}+a_{p 1} \times F_{2}+\ldots+a_{p m} \times F_{m}+e_{p}
$$$$
\text { (equation 1) }
$$

where $X_{p}$ represents the $\mathrm{p}$-th score of the standardized variable $(p=1,2, \ldots \mathrm{m}), F_{m}$ is the extracted factor, $a_{p m}$ is the factor loading, and $e_{p}$ is the error.

Factor scores for each dairy farm were estimated bymultiplyingstandardizedvariables by the coefficient of the corresponding factor score (equation 2):

$F_{j}=d_{j 1} \times X_{1}+d_{j 1} \times X_{2}+\ldots+d_{j p} \times X_{j p}$ (equation 2) where $F_{j}$ is the $j$-th factor extracted, $d_{j p}$ is the factor score coefficient, and $\mathrm{p}$ is the number of variables (Fávero et al., 2009; Hair et al., 2009).
Factor scores were saved as regression variables, and factor loadings were adjusted from the initial correlations between variables. This procedure allowed factor scores to be generated for each farm and used for hierarchical cluster analysis, mean tests, and multiple regression (Field, 2009; Hair et al., 2009).

Principal component analysis was performed on the correlation matrix. The number of extracted factors was determined by the Kaiser criterion (Fávero et al., 2009); that is, factors with eigenvalues less than one were excluded. The eigenvalue of each factor was given by the sum of squared factor loadings of all variables. Communality, which indicates how much a factor explains each variable, was calculated by summing the squared factor loadings of the variables that compose a factor (Hair et al., 2009). Variables with factor loadings of less than 0.60 were excluded (Field, 2009; Hair et al., 2009).

To better interpret the extracted factors, we carried out orthogonal varimax rotation, which minimizes the number of variables that have high loadings in one factor and maximizes the variation between the weights of each factor (Fávero et al., 2009; Hair et al., 2009). After the analytical procedures, 14 variables were maintained in the analysis (Table 1). Factors were named according to the variables that defined them (Koerich et al., 2019). 
Table 1

Farm Management Variables and Scores

Variable Scores

Amount of grain fed to lactating cows

1, Lactating cows are not grain fed; 2 , Up to $4 \mathrm{~kg} \mathrm{cow}^{-1}$ day $^{-1} ; 3$, From 5 to $6 \mathrm{~kg} \mathrm{cow}^{-1}$ day $^{-1} ; 4$, Above $7 \mathrm{~kg} \mathrm{cow}^{-1}$ day $^{-1}$.

1, Herds are not grain fed; 2, Dry and lactating cows;

Grain-fed cows

3, Heifers, dry cows, and lactating cows; 4, All animal categories are grain fed (calves, heifers, dry cows, and lactating cows).

Criteria used to define the amount of grain fed to lactating cows

1, Lactating cows are not grain fed; 2 , No criteria are used, all lactating cows receive the same amount of grain; 3, Milk production; 4, Lactation stage.

Type of grain

1, Animals are not grain fed; 2, Grain by-products; 3 , Grains and grain by-products; 4, Grains only.

1 , Animals are not grain fed; 2 , Soybean meal is

Grain supply purchased, corn is grown on the farm; 3 , Soybean meal and corn are purchased; 4 , Concentrate feed is purchased.

1, Mainly tropical forages; 2 , Tropical forages and winter

Forage base forages (ryegrass and oat grass); 3 , Tropical forages and corn silage; 4, Corn silage; 5, Corn silage, hay, and haylage.

1, Lactating cows are not fed conserved forage; 2 , No

Criteria used to define the amount of conserved forage fed to lactating cows criteria are used, all lactating cows receive the same amount of conserved forage; 3 , Milk production; 4, Lactation stage.

1, Cows are not fed conserved forage; 2 , Dry and lactating cows; 3 , Heifers, dry cows, and lactating cows; 4 , All cows (calves, heifers, dry cows, and lactating cows).

1, Natural breeding; 2, Artificial insemination and

Breeding strategy natural breeding; 3 , Artificial insemination; 4, Fixed-time artificial insemination.

Herd breed composition

1, Undefined breeds not selected for dairy production;

2 , Crossbreds; 3 , Crossbreds with high milk production capacity; 4, Purebreds.

1 , Incomplete primary; 2 , Complete primary; 3 ,

Level of schooling of farm operator Incomplete secondary; 4, Complete secondary; 5, Postsecondary.

1, Family labor (farmer and spouse); 2, Family labor

Labor force characteristics (farmer, spouse, and offspring); 3, Farm owner and hired labor; 4, Hired labor only.

Herd size (n)

Numerical value.

Dairy production area (ha)

Numerical value. 
Suitability of the data for exploratory factor analysis was evaluated using the Kaiser-Meyer-Olkin (KMO) test and Bartlett's sphericity test. A KMO index greater than 0.60 and a significant Bartlett's test $(p<0.05)$ was expected (Fávero et al., 2009; Hair et al., 2009). Exploratory factor analysis allowed identifying the variables that most distinguished the dairy farms and how they related to each other. Condensation of variables into factors also allowed a more objective analysis of data.

We emphasize that the minimum sample size for exploratory factor analysis depends on the quality of the evaluation instrument (Damásio, 2012). A Monte Carlo simulation study demonstrated the stability of factor solutions with one, two, or three observations per variable (Barrett \& Kline, 1981). Barrett and Kline (1981) and MacCallum, Widaman Zhang and Hong (1999) consider that the size of the sample is not a limiting factor for exploratory factor analysis if the following criteria are met: each factor is defined by four or more variables, factor loadings are greater than 0.60 , and communality values are high.

\section{Hierarchical cluster analysis}

The factor scores of each dairy farm, calculated using exploratory factor analysis, were used to form homogenous groups through hierarchical cluster analysis (Bánkuti \& Caldas, 2018; Martínez-García, Ugoretz, Arriaga-Jordán, \& Wattiaux, 2015; Yabe et al., 2015). Hierarchical clustering is a multivariate statistical technique used to group individuals based on their similarity. The tool results in the formation of groups of individuals that show high internal similarity and differ from individuals in other groups (Hair et al., 2009; Zoma-Traoré et al., 2020).
The Euclidean distance measure and the complete linkage method (equation 3) were used for hierarchical clustering:

$d[k,(i j)]=\max [d(k, i), d(k, j)] \quad$ (equation 3 )

This agglomerative algorithm calculates the shortest distance between the two closest elements $i$ and $j$ using the distance matrix $d_{i j}$. Then, the distance between the farthest elements in each cluster is calculated (Hair et al., 2009).

The number of retained clusters was chosen so as to obtain an inter-cluster variance greater than $75 \%$ and an intracluster variance lower than $25 \%$ (Fávero et al., 2009). Validated dairy farm clusters were compared with respect to mean factor scores and performance parameters using the nonparametric Kruskal-Wallis test $(p<0.05)$. The Kruskal-Wallis test was chosen here because clusters were composed of different numbers of elements (Bánkuti et al., 2020; Field, 2009).

\section{Multiple linear regression}

Multiple linear regression was performed to identify significant factors and their explanatory capacity. Factor scores of each dairy farm were considered independent variables, and the six performance parameters were considered dependent variables (Koerich et al., 2019). Stepwise procedures based on the F-test $(p<0.05)$ were used to select factors for the model (Çamdevýren, Demýr, Kanik, \& Keskýn, 2005; Koerich et al., 2019) (equation 4): $y=a+\beta_{1}{ }^{*} A_{s 1}+\beta_{2}{ }^{*} A_{s 2}+\beta_{3}{ }^{*} A_{s 3}+e$ (equation 4) where $y$ is the performance parameter, $a$ is a constant, $\beta$ is the regression coefficient of each factor, $A_{s}$ is the factor score coefficient, and $e$ is the model error. 
Regression coefficients were tested by Student's t-test. The coefficient of determination $\left(R^{2}\right)$ was used as a standard criterion of predictive success (Çamdevýren et al., 2005; Koerich et al., 2019). These procedures allowed finding associations between extracted factors and performance parameters.

All statistical analyses were carried out using IBM SPSS Statistics version 18.

\section{Results and Discussion}

\section{Sample characteristics}

Farm operators had a mean age of $45.00 \pm 11.92$ years and a mean farming experience of $12.00 \pm 9.01$ years. Farms had on average $2.90 \pm 1.41$ workers. The mean total farm size was $78.15 \pm 201.49$ ha; and the mean dairy production area, $19.01 \pm 17.74$ ha. Dairy farms produced on average 626.78 $\pm 790.24 \mathrm{~L}$ of milk per day with $46.22 \pm 48.71$ cows.

The high standard deviation values of dairy farm parameters are evidence of the high heterogeneity between dairy farms analyzed in this study and indicate that sampling criteria were met. The farms are representative of the study region, as previous studies have also shown that dairy farms in central-western Paraná are highly diverse (Bánkuti et al., 2020; Zimpel, Bánkuti, Zambom, Kuwahara, \& Bánkuti, 2017). However, the sample is not representative of dairy farms across Brazil, and, therefore, the results should be interpreted with care.

Our findings agree with those of other studies assessing the sociodemographic characteristics of farm operators (Brito et al., 2015; Casali et al., 2020; Lange et al., 2016) and the production parameters of dairy farms in central-western Paraná (Bánkuti et al., 2020; Yabe et al., 2015). Farm operators were relatively young, with a mean age of 45 years, and had vast experience in the activity, with a mean of 10 years of experience. The production area of dairy farms was on average 20 ha, with a mean of 40 animals per farm, characteristics of small- to medium-sized farms. These types of farms are common in Paraná (Brito et al., 2015; Defante, Damasceno, Bánkuti, \& Ramos, 2019).

In analyzing dairy farms located in Paraná State, Bánkuti et al. (2020) observed high heterogeneity in structural and production characteristics. The analyzed sample had a mean farm size of $20.38 \pm 24.20$ ha, milk production of $290.11 \pm 347 \mathrm{~L} \mathrm{day}^{-1}$, and cow productivity of $12.25 \pm 6.31 \mathrm{~L} \mathrm{cow}^{-1}$ day $^{-1}$. The heterogeneity of farm systems in Paraná State was also demonstrated by Zimpel et al. (2017), who found farm areas ranging from 2 to 211 ha and daily milk production volumes of 40 to $1900 \mathrm{~L} \mathrm{day}^{-1}$. The authors also observed that the age of dairy farm operators ranged from 20 to 71 years.

\section{Extracted factors}

The KMO index (0.774) was adequate, and Bartlett's test of sphericity was significant ( $p<0.05)$, indicating that the data were suitable for factor analysis (Hair etal., 2009). Orthogonal varimax rotation was used because factors were not correlated (Hair et al., 2009). Three orthogonal factors with eigenvalues greater than 1.0 were obtained, which explained $82.61 \%$ of the total variance (Table 2). Factor 
loading and communality values confirmed the good quality of the sample and the adequacy of the sample size (Barrett \& Kline, 1981; MacCallum et al., 1999). In exploratory factor analysis, extracted factors generally explain $70 \%$ or more of the total variance, and the first factor explains a higher percentage of the variance than the other factors (García et al., 2012; Martínez-García et al., 2015; Mele et al., 2016).
The variables that defined and characterized each factor are presented in Table 3. The first factor, F1, was named "Diet quality, technology, and breed composition." F1 explained $42.04 \%$ of the total variance of the sample (Table 2) and was defined by nine variables (V1-V9). The mean communality was $81 \%$ (Table 3). F1 was an indicator of increased roughage and concentrate quality, highlevel breeding technology, and herd breed composition.

\section{Table 2}

\section{Eigenvalues and Percentages of Variance Explained}

\begin{tabular}{|cccc|}
\hline Factor & Eigenvalue $^{\mathrm{a}}$ & \% of Variance & Cumulative $^{\mathrm{b}}{ }^{\mathrm{c}}$ \\
\hline Factor 1 & 5.88 & 42.04 & 42.04 \\
\hline Factor 2 & 3.30 & 23.55 & 65.60 \\
\hline Factor 3 & 2.38 & 17.01 & 82.61 \\
\hline
\end{tabular}

asum of squared factor loadings.

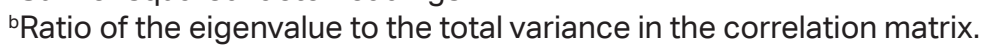

'Sum of the variances accounted for by current and preceding factors.

The second factor (F2), labeled "Labor and size" explained $23.55 \%$ of the total variance (Table 2). F2 was defined by variables V10, $\mathrm{V} 11$, and $\mathrm{V} 12$, which had a mean communality of $89 \%$ (Table 3). F2 was an indicator of the production scale and productive capacity of dairy farms. It was associated with farm size and type of labor force.
The third factor (F3), labeled "Feed quality and schooling," explained $17.01 \%$ of the total variance (Table 2). F3 comprised variables V13 and V14, which had an average communality of $80 \%$ (Table 3). F3 indicated the level of control over the choice and origin of concentrate used in cattle diets and the decision maker's level of schooling. 
Table 3

Factor Loadings of Farm Variables

\begin{tabular}{|c|c|c|c|c|}
\hline \multirow[b]{2}{*}{ Variable } & \multicolumn{4}{|c|}{ Factors } \\
\hline & F1 & $\mathbf{F 2}$ & $\mathbf{F 3}$ & Com $(\%)^{a}$ \\
\hline V1. Amount of grain fed to lactating cows & 0.864 & 0.244 & 0.280 & 88 \\
\hline V2. Grain-fed cows & 0.889 & 0.166 & 0.117 & 83 \\
\hline $\begin{array}{l}\text { V3. Criteria used to define the amount of grain fed to } \\
\text { lactating cows }\end{array}$ & 0.634 & -0.108 & 0.604 & 78 \\
\hline V4. Type of grain & 0.755 & -0.009 & 0.423 & 75 \\
\hline V5. Forage base & 0.799 & 0.383 & 0.265 & 86 \\
\hline $\begin{array}{l}\text { V6. Criteria used to define the amount of conserved } \\
\text { forage fed to lactating cows }\end{array}$ & 0.870 & 0.053 & 0.159 & 78 \\
\hline V7. Cows fed conserved forage & 0.940 & 0.192 & 0.025 & 92 \\
\hline V8. Herd breed composition & 0.649 & 0.228 & 0.467 & 69 \\
\hline V9. Breeding strategy & 0.632 & 0.626 & 0.143 & 81 \\
\hline V10. Herd size & 0.149 & 0.925 & -0.032 & 88 \\
\hline V11. Dairy production area & 0.086 & 0.932 & -0.051 & 88 \\
\hline V12. Labor force characteristics & 0.233 & 0.780 & 0.485 & 90 \\
\hline V13. Grain supply & 0.435 & -0.304 & 0.706 & 78 \\
\hline V14. Level of schooling of farm operator & 0.068 & 0.379 & 0.821 & 82 \\
\hline Eigeinvalue $^{\mathrm{b}}$ & 5.88 & 3.30 & 2.38 & \\
\hline
\end{tabular}

${ }^{a}$ Communality, calculated using the sum of squared factor loadings of each variable.

bSum of squared factor loadings of each factor.

F1, "Diet quality, technology, and breed composition," can be considered an indicator of the quality and quantity of roughage and concentrate in dairy cow diets and of the technological input given to breeding management, which is associated with herd breed composition (Table 4). Thus, a high factor score on F1 indicates that the farmer is more likely to include large amounts of grains in cattle diets, have purebred cows, and adopt breeding strategies.

Dairy cows fed high-quality roughage together with concentrate have higher milk production (Auldist et al., 2013; Macdonald et al., 2017). In general, preserved forage is used in total or semi-confinement systems. In these cases, grains are supplied to contribute to the daily nutrient intake. Biradar and Kumar (2013) investigated the application of this nutrition strategy in rural farms. The authors evaluated the contribution of different sources of grains and preserved forage to dry matter availability. Concentrate was found to contribute less when the amount of pasture in the diet was higher.

In farms that depend exclusively on perennial forages, the supply of forage might not be consistent throughout the year because of climatic variations (Hills et al., 2015). In such cases, the use of preserved 
forage is an important alternative in periods of drought in tropical areas (Daniel, Bernardes, Jobim, Schmidt, \& Nussio 2019; ProsperoBernal et al., 2017). If the roughage is of good quality, it will be able to meet the maintenance requirements of dairy cows, and thus nutrients provided by grains will mostly be used for the synthesis of milk (National Resarch Council [NRC], 2001).

The present study showed that farmers who fed lactating cows with grains do so according to the physiological state of the animal. This statement can be observed by the interaction of V3 (criteria used to define the amount of grain fed to lactating cows) with the other variables that defined F1 (Diet quality, technology, and breed composition) (Table 3). DeVries et al. (2011) reported that Holstein dairy cows at different stages of lactation (days 53, 81, and 109) showed significant differences in dry matter intake, feed efficiency, and milk production. This practice suggests greater knowledge of animal nutrition, despite the non-correlation with schooling level, as observed by the variables that formed F3 (Feed quality and schooling) (Table 3).

Different dairy breeds have different nutritional requirements and differ in their ability to convert dietary components into milk (NRC, 2001). Consequently, it is easier to formulate diets for purebred cows. The best responses to grain intake are observed in cow breeds specialized for milk production ( $\mathrm{Li}$ et al., 2016; Yabe et al., 2015). We observed that farms in which lactating cows were fed the highest amounts of grains used breeds specialized for milk production and guaranteed year-round supply of quality roughage. This relationship was also reported by Yabe et al. (2015). The authors concluded that farms that do not grain feed generally have nonspecialized cow breeds.

The variables that composed F2, "Labor and size," and F3, "Feed quality and schooling," had no relationship with the amount of grains supplied to lactating cows nor with diet quality, breeding strategy, or herd breed composition (Table 3). The lack of association between $\mathrm{F} 1$ and $\mathrm{F} 2$ variables is in agreement with the results of Santos, Santana, Raiol and Lourenço (2014) and Zoma-Traoré et al. (2020), who observed that nutritional management variables were not associated with production scale.

Extraction of F3 indicated that there was no relationship between the amount and the type of grain, whether feed grain or commercial concentrate, used in cattle diets. We expected that farmers who bought grains would use higher amounts of grains. Farmers can benefit from buying grains at lower prices during the harvest season. However, this practice was not observed. Farmers purchased grain on a monthly basis, thereby not making use of the storage capacity of their farms, probably because they did not have enough money to buy large volumes of grain in low-price seasons (Bonazzi \& lotti, 2014). In addition, the results indicated that farmers with higher levels of schooling chose a better alternative by purchasing commercial concentrate. In this manner, they ensured that the nutritional requirements of the dairy cows were met, lowering the risks of nutritional deficiencies. Indeed, literature has shown the influence of formal education regarding the adoption of dairy technologies (Kebebe, Oosting, Baltenweck, \& Duncan et al., 2017; Khanal, Gillespie, \& Macdonald, 2010). 


\section{Cluster analysis}

Hierarchical cluster analysis identified four groups, G1, G2, G3, and G4, composed respectively of $45.5 \%(n=10), 22.7 \%(n=5)$,
$13.6 \%(n=3)$, and $18.2 \%(n=4)$ of the dairy farms. $\mathrm{G} 1$ had the highest mean score on $\mathrm{F} 1$ (0.715), G4 on F2 (1.642), and G2 on F3 (1.116) (Table 4).

\section{Table 4}

\section{Mean Factor Scores of Dairy Farm Groups}

\begin{tabular}{ccccc}
\hline Factor & Group 1 & Group 2 & Group 3 & Group 4 \\
\hline F1 $^{\mathrm{a}}$ & $0.715 \mathrm{a}$ & $-0.786 \mathrm{~b}$ & $-1.582 \mathrm{~b}$ & $0.380 \mathrm{ab}$ \\
$\mathrm{F}^{\mathrm{b}}$ & $-0.517 \mathrm{~b}$ & $-0.389 \mathrm{~b}$ & $0.184 \mathrm{ab}$ & $1.642 \mathrm{a}$ \\
F3 $^{\mathrm{c}}$ & $-0.138 \mathrm{~b}$ & $1.116 \mathrm{a}$ & $-1.583 \mathrm{~b}$ & $0.138 \mathrm{ab}$
\end{tabular}

Means within a row followed by different letters differ at the $5 \%$ significance level according to the Kruskal-Wallis test. aFactor 1, diet quality, technology, and breed composition.

${ }^{\text {b} F a c t o r ~ 2, ~ l a b o r ~ a n d ~ s i z e . ~}$

'Factor 3, feed quality and schooling.

G1 and G4 had similar performance parameters (Table 4). G1 and G4 had the highest mean daily productivity (399.52 L day $^{-1}$ and $2043.50 \mathrm{~L} \mathrm{day}^{-1}$, respectively) and labor efficiency (148.63 $\mathrm{L}_{\text {worker }}{ }^{-1}$ day $^{-1}$ and 418.16 $\mathrm{L}$ worker $^{-1}$ day $^{-1}$, respectively). The mean number of cows per worker (25.52) was highest in G4 and did not differ among G1, G2, and G3.

G1 and G4 comprised farms with better diets, breeding strategies, and herd breeds, that is, a higher F1 score (Table 4). Farmers that were part of these groups used grains in cattle diets, adapted the diet according to the physiological state of the cow, used reproductive technologies, and had herds with improved genetic characteristics. To increase the use of grains and milk productivity, farmers must improve the nutritional quality of diets, which can be achieved by pasture fertilization and improved production of maize silage (Daniel et al., 2019; Macdonald et al., 2017).
G2 and G3 comprised farms that used lower amounts of grains in dairy cattle diets. No differences were observed between these two groups (Table 4). To increase grain use and productivity, farmers should use breeds that are more specialized for milk production and should adopt reproductive technologies, such as fixed-time artificial insemination (Fleming, Abdalla, Maltecca, \& Baes 2018). We suggest adequate forage management and the use of preserved forages during drought periods as additional strategies to meet animal nutrition requirements (Daniel et al., 2019; Macdonald et al., 2017; Prospero-Bernal et al., 2017). Based on these results, we can conclude that the amount of grains used to feed cows is a decision influenced by many variables and dairy farm characteristics, such as roughage quality, breeding technology, and herd breed composition. Lima, Damasceno, Borges, Santos and Bánkuti (2020), in studying the sociopsychological factors that may influence 
the adoption of grain feeding, stated that farmers act as autonomous actors who can be encouraged by information or incentives but are not influenced by what their peers think.

\section{Multiple linear regression of extracted factors}

Regression analysis revealed that F1 explained $43 \%$ of the variance in cow productivity and F2 explained $52 \%$ of the variance in the number of cows per worker. None of the extracted factors explained the variances observed in stocking density and productivity per area (Table 6).

\section{Table 5}

\section{Performance of Dairy Farm Groups}

\begin{tabular}{|c|c|c|c|c|}
\hline Variable & Group 1 & Group 2 & Group 3 & Group 4 \\
\hline Cow productivity $\left(\mathrm{L} \mathrm{cow}^{-1}\right.$ day $\left.^{-1}\right)$ & 14.58 & 9.65 & 5.15 & 16.88 \\
\hline Daily production ( $\left(\right.$ day $\left.^{-1}\right)$ & $399.52 a b$ & $226.79 \mathrm{~b}$ & $162.01 \mathrm{~b}$ & $2043.50 a$ \\
\hline Productivity per area $\left(\mathrm{L} \mathrm{ha}^{-1}\right.$ day $\left.^{-1}\right)$ & 45.01 & 46.00 & 22.00 & 46.70 \\
\hline Stocking density (cows ha-1) & 3.02 & 4.61 & 3.10 & 2.73 \\
\hline Labor efficiency (L worker-1 day ${ }^{-1}$ ) & $148.63 \mathrm{ab}$ & $103.06 \mathrm{~b}$ & $81.00 \mathrm{~b}$ & 418.16 a \\
\hline Number of cows per worker (cows worker ${ }^{-1}$ ) & $10.68 \mathrm{~b}$ & $11.87 b$ & $19.33 \mathrm{~b}$ & $25.52 \mathrm{a}$ \\
\hline
\end{tabular}

Means within a row followed by different letters differ at the $5 \%$ significance level according to the Kruskal-Wallis test.

\section{Table 6}

Regression Coefficients $\left(\beta_{1}, \beta_{2}\right.$, and $\left.\beta_{3}\right)$ of Extracted Factors for Each Performance Parameter

\begin{tabular}{|c|c|c|c|c|c|}
\hline Variable & $\begin{array}{c}\text { Constant } \\
\text { (SEa) }\end{array}$ & $\begin{array}{c}\beta_{1} \\
(S E)\end{array}$ & $\underset{\left(\mathrm{SE}_{2}\right)}{\beta_{2}}$ & $\underset{(\mathrm{SE})}{\beta_{3}}$ & $\begin{array}{c}R^{2} \\
(\%)\end{array}$ \\
\hline Cow productivity (L cow ${ }^{-1}$ day $\left.^{-1}\right)$ & $\begin{array}{l}12.60 * \\
(0.92)\end{array}$ & $\begin{array}{l}3.63^{*} \\
(0.95)\end{array}$ & - & - & 43 \\
\hline Daily production (L day $\left.{ }^{-1}\right)$ & $\begin{array}{l}626.71^{*} \\
(66.65)\end{array}$ & $\begin{array}{l}253.0{ }^{*} \\
(68.22)\end{array}$ & $\begin{array}{l}687.00 * \\
(68.22)\end{array}$ & - & 93 \\
\hline Productivity per area (L ha ${ }^{-1}$ day $^{-1}$ ) & - & - & - & - & - \\
\hline Stocking density (cows ha-1) & - & - & - & - & - \\
\hline Labor efficiency (L worker ${ }^{-1}$ day $^{-1}$ ) & $\begin{array}{l}\text { 178.10* } \\
(16.01)\end{array}$ & $\begin{array}{c}50.65^{*} \\
(16.46)\end{array}$ & $\begin{array}{l}104.07^{*} \\
(16.46)\end{array}$ & - & 72 \\
\hline Number of cows per worker (cows worker ${ }^{-1}$ ) & $\begin{array}{l}14.83^{*} \\
(1.37)\end{array}$ & - & $\begin{array}{l}6.56^{*} \\
(1.41)\end{array}$ & - & 52 \\
\hline
\end{tabular}

aStandard error.

*Significant at the $5 \%$ significance level according to Student's $t$-test. 
$\mathrm{F} 1$ and $\mathrm{F} 2$ explained $93 \%$ and $72 \%$ of the variance in daily productivity and labor efficiency, respectively. Their regression coefficients, $\beta 1$ and $\beta 2$, were positive for all variables that showed significance (Table 6).

Multivariate models capable of evaluating a large number of variables can be used to characterize and predict complex processes (Çamdevýren et al., 2005), such as dairy farms. Multiple linear regression was carried out using factor scores as independent variables to elucidate the relationship between a large number of farm management variables and performance parameters. We observed that F1 was associated with daily productivity, cow productivity, and labor efficiency. Therefore, gains in productivity and efficiency can be obtained by improving breeding strategies, genetic characteristics of the herd, and the diet fed to lactating cows.

Other studies achieved similar results. Koerich et al. (2019), using similar methods to analyze dairy systems in Paraná State, found a positive relationship between variables related to forage production area and concentrate supply and dairy system productivity. They also found a positive relationship between sociodemographic characteristics of dairy farmers and productivity parameters. Dias and Fischer (2021), observed a positive correlation between grain feeding and milk productivity per cow and area. Furthermore, the authors observed a negative correlation between the use of low-quality forage and productivity per cow and area.

Overall, we can state that several variables and systemic factors may interfere in the amount and frequency of grains fed to dairy cattle, including roughage quality, breeding technology, and herd breed composition.

\section{Conclusion}

The findings showed that, in the analyzed sample, the use of high-grain feeding was associated with roughage quality, breeding technology, and herd breed composition. Furthermore, farmers who fed cows high-quality roughage throughout the year and invested in genetic improvement and selective breeding strategies were more likely to include high levels of grains in cattle diets, thereby increasing milk productivity. Grain type, herd size, farm area, farm operator's level of schooling, and labor force characteristics showed no association with grain feeding in this study.

\section{Acknowledgements}

Funding for this research was provided by the Brazilian National Research Council (CNPq, grant no. 312258/2014-3).

\section{References}

Auldist, M. J., Marett, L. C., Greenwood, J. S., Hannah, M., Jacobs, J. L., \& Wales, W. J. (2013). Effects of different strategies for feeding supplements on milk production responses in cows grazing a restricted pasture allowance. Journal of Dairy Science, 96(2), 1218-1231. doi: 10.3168/ jds.2012-6079

Bánkuti, F. I., \& Caldas, M. M. (2018). Geographical milk redistribution in Paraná State, Brazil: Consequences of institutional and market changes. Journal of Rural Studies, 64, 63-72. doi: 10.1016/j. jrurstud.2018.10.004 
Bánkuti, F. I., Caldas, M. M., Bánkuti, S. M. S., \& Granco, G. (2017). Spatial dynamics: a new milk corridor in Paraná state, Brazil. Semina: Ciências Agrárias, 38(4), 21072117. doi: 10.5433/1679-0359.2017v38 n4p2107

Bánkuti, F. I., Prizon, R. C., Damasceno, J. C., Brito, M. M. de, Pozza, M. S. S., \& Lima, P. G. L. (2020). Farmers' actions toward sustainability: a typology of dairy farms according to sustainability indicators. Animal, 14(2), 417-423. doi: 10.1017/S17 51731120000750

Baptista, J. R. V, Sugamosto, M., \& Wavruk, P. (2011). Características e perspectivas da industria de laticínios do Paraná. Caderno Ipardes, 1(1), 32-46.

Bargo, F., Muller, L. D., Kolver, E. S., \& Delahoy, J. E. (2003). Invited review: production and digestion of supplemented dairy cows on pasture. Journal of Dairy Science, 86(1), 1-42. doi: 10.3168/jds.S0022-0302 (03)73581-4

Barrett, P., \& Kline, P. (1981). The observation to variable ratio in factor analysis. Personality Study and Group Behavior, 1(1), 23-33.

Beber, C. L., Carpio, A. F. R., Almadani, M. I., \& Theuvsend, L. (2019). Dairy supply chain in Southern Brazil: barriers to competitiveness. International Food and Agribusiness Management Review, 22(5), 651-673. doi: 10.22434/IFAMR2018.0091

Biradar, N., \& Kumar, V. (2013). Analysis of fodder status in Karnataka. Indian Journal of Animal Sciences, 83(10), 1078-1083.

Bonazzi, G., \& lotti, M. (2014). Interest coverage ratios (ICRs) and financial sustainability: application to firms with bovine dairy livestock. American Journal of Agricultural and Biological Sciences, 9(4), 482-489. doi: 10.3844/ajabssp.2014.482.489

Brito, M. M., Bánkuti, F. I., Bánkuti, S. M. S., Santos, G. T., Damasceno, J. C., \& Massuda, E. M. (2015). Horizontal arrangements and competitiveness of small-scale dairy farmers in Paraná, Brazil. International Food and Agribusiness Management Review, 18(4), 18. doi: 10.22004/ag.econ. 211658. Retrieved from https://www. ifama.org/files/IFAMR/Volume18/Issue4/ 820150022.pdf

Çamdevýren, H., Demýr, N., Kanik, A., \& Keskýn, S. (2005). Use of principal component scores in multiple linear regression models for prediction of Chlorophyll-a in reservoirs. Ecological Modelling, 181(4), 581-589. doi: 10.1016/j. ecolmodel.2004.06.043

Casali, M., Mendonça, B. S. de, Brito, M. M. de, Rojas, G., Gustavo, P., Lima, L., Teixeira, T., Damasceno, J. C.,... Bánkuti, F. I. (2020). Information asymmetry among dairy producers in Paraná, Brazil. Semina: Ciências Agrárias, 41(1), 295-306. doi: 10.5433/1679-0359.2020v41n1p295

Damásio, B. F. (2012). Uso da análise fatorial exploratória em psicologia. American Journal of Physiology-Gastrointestinal and Liver Physiology, 11(2), 213-228. doi: 10.1152/ajpgi.00568.2005

Daniel, J. L. P., Bernardes, T. F., Jobim, C. C., Schmidt, P., \& Nussio, L. G. (2019). Production and utilization of silages in tropical areas with focus on Brazil. Grass and Forage Science, 74(2), 188-200. doi: $10.1111 / \mathrm{gfs} .12417$ 
Defante, L., Damasceno, J. C., Bánkuti, F. I., \& Ramos, C. E. C. de O. (2019). Typology of dairy production systems that meet Brazilian standards for milk quality. Revista Brasileira de Zootecnia, 48(e20180023), 1-8. doi: 10.1590/rbz4820180023

Denis-Robichaud, J., Cerri, R. L. A., JonesBitton, A., \& LeBlanc, S. J. (2016). Survey of reproduction management on Canadian dairy farms. Journal of Dairy Science, 99(11), 9339-9351. doi: 10.3168/jds.20 16-11445

DeVries, T. J., Holtshausen, L., Oba, M., \& Beauchemin, K. A. (2011). Effect of parity and stage of lactation on feed sorting behavior of lactating dairy cows. Journal of Dairy Science, 94(8), 4039-4045. doi: 10.3168/jds.2011-4264

Dias, A. P., \& Fischer, V. (2021). Use of qualiquantitative feeding practices criteria in typology of smallholders' dairy production systems. Revista Brasileira de Zootecnia, 50(e20200283), 1-11. doi: 10.37496/rbz 5020200283

Duncan, A. J., Teufel, N., Mekonnen, K., Singh, V. K., Bitew, A., \& Gebremedhin, B. (2013). Dairy intensification in developing countries: effects of market quality on farm-level feeding and breeding practices. Animal, 7(12), 2054-2062. doi: 10.1017/S1751731113001602

Fávero, L. P., Belfiore, P. P., Silva, F. L. da, \& Chan, B. L. (2009). Análise de dados: modelagem multivariada para tomada de decisões (3nd ed., p. 544). Rio de Janeiro: CampusElsevier.

Field, A. (2009). Descobrindo a estatística usando o SPSS (2nd ed.). Porto Alegre: Artmed.
Fleming, A., Abdalla, E. A., Maltecca, C., \& Baes, C. F. (2018). Invited review: reproductive and genomic technologies to optimize breeding strategies for genetic progress in dairy cattle. Archives Animal Breeding, 61(1), 43-57. doi: 10.5194/aab-61-432018

García, C. G. M., Dorward, P., \& Rehman, T. (2012). Farm and socio-economic characteristics of smallholder milk producers and their influence on technology adoption in Central Mexico. Tropical Animal Health and Production, 44, 1199-1211. doi: 10. 1007/s11250-011-0058-0

Goes, R. H. de T. e B. de, Silva, L. H. X. da, \& Souza, K. A. de. (2013). Alimentos e alimentação animal (Issue March 2013). Dourados: Editora UFGD.

Gonzalez-Rivas, P. A., Sullivan, M., Cottrell, J. J., Leury, B. J., Gaughan, J. B., \& Dunshea, F. R. (2018). Effect of feeding slowly fermentable grains on productive variables and amelioration of heat stress in lactating dairy cows in a subtropical summer. Tropical Animal Health and Production, 50(8), 1763-1769. doi: 10.1007/s11250-018-1616-5

Hair, J. F. J., Black, W. C., Babin, B. J., \& Anderson, R. E. (2009). Multivariate data analysis (7nd ed.). Saddle River: Prentice Hall.

Hills, J. L., Wales, W. J., Dunshea, F. R., Garcia, S. C., \& Roche, J. R. (2015). Invited review: an evaluation of the likely effects of individualized feeding of concentrate supplements to pasture-based dairy cows. Journal of Dairy Science, 98(3), 1363-1401. doi: 10.3168/jds.2014-8475

Hurtaud, C., Chesneau, G., Coulmier, D., \& Peyraud, J. L. (2013). Effects of extruded 
linseed or alfalfa protein concentrate in interaction with two levels of concentrates on milk production and composition in dairy cows. Livestock Science, 158(1-3), 64-73. doi: 10.1016/j.livsci.2013.10.002

Hynes, D. N., Stergiadis, S., Gordon, A., \& Yan, T. (2016). Effects of crude protein level in concentrate supplements on animal performance and nitrogen utilization of lactating dairy cows fed fresh-cut perennial grass. Journal of Dairy Science, 99(10), 8111-8120. doi: 10.3168/jds.20 $16-11110$

Instituto Brasileiro de Geografia e Estatística (2017). Censo Agropecuário (vol. 7). Rio de Janeiro: IBGE.

Janssen, E., \& Swinnen, J. (2019). Technology adoption and value chains in developing countries: evidence from dairy in India. Food Policy, 88(March) 327-336. doi: 10.1016/j.foodpol.2017.08.005

Jiao, H. P., Dale, A. J., Carson, A. F., Gordon, A. W., \& Ferris, C. P. (2014). Effect of concentrate feed level on methane emissions from grazing dairy cows. Journal of Dairy Science, 97(11), 70437053. doi: 10. 3168/jds.2014-7979

Kebebe, E. G., Oosting, S. J., Baltenweck, I., \& Duncan, A. J. (2017). Characterisation of adopters and non-adopters of dairy technologies in Ethiopia and Kenya, 49(4), 681-690. doi: 10.1007/s11250-017-12 41-8

Khanal, A. R., Gillespie, J., \& Macdonald, J. (2010). Adoption of technology, management practices, and production systems in US milk production. Journal of Dairy Science, 93(12), 6012-6022. doi: $10.3168 /$ jds.2010-3425
Koerich, G., Damasceno, J. C., Bánkuti, F. I., Parré, J. L., \& Santos, G. T. dos. (2019). Influence of forage production area, concentrate supply, and workforce on productive results in milk production systems. Revista Brasileira de Zootecnia, 48(e20170177), 1-11. doi: 10.1590/rbz48 20170177

Lange, M. J., Zambom, M. A., Ramos, C. E. C. de O., Castagnara, D. D., Bánkuti, F. I., Neumann, M. E.,... Tinini, R. C. dos R. (2016). Typology of dairy production systems based on the characteristics of management in the Region of West Paraná. Semina: Ciências Agrárias, 37(1), 473. doi: 10.5433/1679-0359.2016v37n1p473

Li, B., Fikse, W. F., Lassen, J., Lidauer, M. H., Løvendahl, P., Mäntysaari, P., \& Berglund, B. (2016). Genetic parameters for dry matter intake in primiparous Holstein, Nordic Red, and Jersey cows in the first half of lactation. Journal of Dairy Science, 99(9), 7232-7239. doi: 10.3168/jds.201510669

Lima, P. G. L., Damasceno, J. C., Borges, J. A. R., Santos, G. T. dos, \& Bánkuti, F. I. (2020). Short communication: sociopsychological factors influencing dairy farmers' intention to adopt high-grain feeding in Brazil. Journal of Dairy Science, 103(11), 10283-10288. doi: 10.3168/ jds.2020-18475

MacCallum, R. C., Widaman, K. F., Zhang, S., \& Hong, S. (1999). Sample size in factor analysis. Psychological Methods, 4(1), 8499. doi: 10.1037/1082-989X.4.1.84

Macdonald, K. A., Penno, J. W., Lancaster, J. A. S., Bryant, A. M., Kidd, J. M., \& Roche, J. R. (2017). Production and economic responses to intensification of pasture- 
based dairy production systems. Journal of Dairy Science, 100(8), 6602-6619. doi: 10.3168/jds.2016-12497

Martínez-García, C. G., Ugoretz, S. J., Arriaga-Jordán, C. M., \& Wattiaux, M. A. (2015). Farm, household, and farmer characteristics associated with changes in management practices and technology adoption among dairy smallholders. Tropical Animal Health and Production, 47, 311-316. doi: 10.1007/s11250-0140720-4

Mele, M., Macciotta, N. P. P., Cecchinato, A., Conte, G., Schiavon, S., \& Bittante, G. (2016). Multivariate factor analysis of detailed milk fatty acid profile: effects of dairy system, feeding, herd, parity, and stage of lactation. Journal of Dairy Science, 99(12), 9820-9833. doi: 10.3168/ jds.2016-11451

Mendes, F. B. L., Silva, F. F. da, Silva, R. R., Carvalho, G. G. P. de, Cardoso, E. O., Rocha, A. L., Neto,... Pinheiro, A. A. (2013). Avaliação do comportamento ingestivo de vacas leiteiras em pastejo de Brachiaria brizantha recebendo diferentes teores de concentrado na dieta. Semina: Ciências Agrárias, 34(6), 2977-2990. doi: 10.5433/1679-0359.2013v34n6p2977

National Resarch Council (2001). Nutrient requeriments of dairy cattle ( $7 \mathrm{nd}$ ed.). Washington: The National Academies Press.

Prospero-Bernal, F., Martínez-García, C. G., Olea-Pérez, R., López-González, F., \& Arriaga-Jordán, C. M. (2017). Intensive grazing and maize silage to enhance the sustainability of small-scale dairy systems in the highlands of Mexico. Tropical Animal Health and Production, 49, 1537-1544. doi: 10.10 07/s11250-017-1360-2
Santos, M. A. S. dos, Santana, A. C. de, Raiol, L. C. B., \& Lourenço de B., Jr. (2014). Fatores tecnológicos de modernização da pecuária leiteira no estado do tocantins. Revista em Agronegócio e Meio Ambiente, 7(3), 519-612. doi: 10.4013/pe.2011.72.03

Secretaria de Estado da Agricultura e do Abastecimento (2019a). Milho - análise da conjuntura. Curitiba: DERAL.

Secretaria de Estado da Agricultura e do Abastecimento (2019b). Soja - análise da conjuntura. Curitiba: DERAL.

Simões, A. R. P., Reis, J. D. dos, \& Avelar, P. S. (2017). A heterogeneidade tecnológica da pecuária leiteira em Minas Gerais. Revista Agrarian, 10(37), 261-269. doi: 10.30612/ agrarian.v10i37.6782

Yabe, M., Bánkuti, F. I., Damasceno, J. C., \& Brito, M. M. de. (2015). Characteristics of milk production systems and feed strategies for dairy cows in the North and Northwest of Paraná State. Semina: Ciências Agrárias, 36(6), 4469-4480. doi: 10.5433/1679-03 59.2015v36n6Supl2p4469

Zimpel, R., Bánkuti, F. I., Zambom, M. A., Kuwahara, K. C., \& Bánkuti, S. M. S. (2017). Characteristics of the dairy farmers who perform financial management in Paraná State, Brazil. Revista Brasileira de Zootecnia, 46(5), 421-428. doi: 10.1590/ S1806-92902017000500008

Zoma-Traoré, B., Soudré, A., Ouédraogo-Koné, S., Khayatzadeh, N., Probst, L., Sölkner, J.,... Wurzinger, M. (2020). From farmers to livestock keepers: a typology of cattle production systems in south-western Burkina Faso. Tropical Animal Health and Production, 52, 2179-2189. doi: 10.1007/ s11250-020-02 241-6 